\title{
Lack of Toxicity of Oral and Intrapulmonary Group B Streptococcal Lipoteichoic Acid
}

\author{
FREDERICK COX, ELIZABETH COOK, AND CHARLES LUTCHER
}

Department of Pediatrics and Medicine, Medical College of Georgia, Augusta, Georgia 30912

\begin{abstract}
Lipoteichoic acid (LTA) was prepared from type III group B streptococci and administered by topical oral application or intravenous or intratracheal injection in weanling and adult white New Zealand rabbits. Tritiated $\left[{ }^{3} \mathrm{H}\right]$ LTA in tissues and body fluids was measured by scintillation spectrometry. Five minutes to $120 \mathrm{~h}$ after intravenous injection of $10 \mathrm{mg}\left(17 \times 10^{6} \mathrm{dpm}\right)$ of $\left[{ }^{3} \mathrm{H}\right] \mathrm{LTA}$, none was present in blood. Combined urine and fecal excretion peaked at $24 \mathrm{~h}$ and decreased over 5 days. There was no effect on collagen-induced platelet aggregation. $\left[{ }^{3} \mathrm{H}\right]$ LTA concentrations were greatest in colon, bone, stomach, and skin 1 day after intravenous injection. After a 5-mg oral dose $\left(8.5 \times 10^{6} \mathrm{dpm}\right)$ in an adult animal, fecal excretion peaked at $24 \mathrm{~h}$ and decreased after 4 days. No systemic absorption was noted. No $\left[{ }^{3} \mathrm{H}\right] \mathrm{LTA}$ was found in any of seven tissues examined at autopsy 3 days after 1 to $5 \mathrm{mg}$ / $\mathrm{kg}$ oral doses in weanling animals with normal or traumatized buccal mucosa. No effect was noted on platelet aggregation or serum complement, there was no increase in the incidence of nephrocalcinosis and the buccal mucosa remained histologically normal. Intratracheal injection of 0.5 to $2.5 \mathrm{mg} / \mathrm{kg}$ of $\mathrm{LTA}$ resulted in no tachypnea or alteration in blood gases. All animals remained healthy after LTA administration. The absence of toxicity and absorption in animals suggests that studies could be performed in humans to evaluate the safety and efficacy of oral LTA. (Pediatr Res 20: 1168-1173, 1986)
\end{abstract}

\section{Abbreviations}

GBS, group B streptococci

IV, intravenous

LTA, lipoteichoic acid

IM, intramuscular

PBS, phosphate-buffered saline

r-RBC, rabbit red blood cells

$\left[{ }^{3} \mathrm{H}\right]$, tritium

dpm, disintegrations per minute

At present, there is no widely acceptable or recommended method of prevention of GBS colonization or disease in neonates $(1,2)$. Current investigative techniques include the use of maternal and neonatal antibiotics or a maternal vaccine. Prevention of neonatal colonization by interfering with GBS adherence to mucosal surfaces in the mother and/or infant could provide an alternative method of prophylaxis.

LTA is the ligand that attaches GBS to oral epithelial cells (3,

Received August 22, 1985; accepted June 26, 1986.

Address for correspondence and reprints Frederick Cox, M.D., Department of Pediatrics, Medical College of Georgia, Augusta, GA 30912.
4). A previous study has shown that LTA from GBS completely inhibits maternal-newborn transmission of GBS in a newborn mouse model (5). No toxicity was observed but specific tests of dose response, absorption, and excretion were not performed.

Studies of toxicity have been done primarily with LTA from group $\mathrm{A}$ and other streptococci. In vitro toxicity has included anticomplementary activity $(6)$, variable mitogenicity $(7,8)$, and interference with platelet aggregation (9). In tissue culture, cytotoxicity to human heart, liver, and renal cells (10-12), stimulation of fetal rat bone resorption (13), and lysosomal enzyme release from macrophages (14) were observed. In vivo toxicity includes hypersensitivity (15) and nephropathy in rabbits (16) when LTA was complexed with bovine serum albumin and given IV with Freund's incomplete adjuvant; nephrocalcinosis, when given IV for $3 \mathrm{wk}$ in rabbits (17); decreased antibody response to intraperitoneal sheep red blood cells in mice (18); and immune arthritis when given by intraarticular injection in rabbits (19). Lipoteichoic acid from GBS has recently been shown to produce respiratory distress, pulmonary hemorrhage, and death when aspirated by mice $(20,21)$. However, the plain water-soluble preparation when given by IV, intraperitoneal, intradermal, or subcutaneous injection to over 100 rabbits and several thousand mice for varying periods up to $1 \mathrm{yr}$ and total doses of $100 \mathrm{mg}$ in rabbits produced no antibody response or toxicity (15).

\section{METHODS}

LTA. A wild strain type III (DS-2434-80) GBS was used as the source organism. LTA was prepared by a modified method of Alkan and Beachey (22) in which hot hydrochloric acid extraction was omitted. About $80 \mathrm{mg}$ of a tan crystalline solid was obtained from the phenol extract of 4 liters of Todd-Hewitt broth culture as previously described (5). The final product had a total protein content of $<1.0 \%$ by weight (Bradford method). It contained no residual phenol (no ultraviolet absorbance at 200 $\mu$ ) or penicillin. Adherence of GBS to human buccal epithelial cells in vitro was reduced by $69 \%(0.5 \mathrm{mg} / \mathrm{ml} \mathrm{LTA})(5)$. The final preparation was dissolved in PBS $(0.02 \mathrm{M}$ phosphate, $0.15 \mathrm{M}$ $\mathrm{NaCl}, \mathrm{pH} \mathrm{7.4)}$ and stored frozen in small aliquots at $-70^{\circ} \mathrm{C}$.

Tritiated $\left[{ }^{3} \mathrm{H}\right] \mathrm{LTA}$ was prepared by the method of Alkan and Beachey (22) by adding $4 \mathrm{mCi}$ of $\left[2-{ }^{3} \mathrm{H}\right]$ glycerol (New England Nuclear, Boston, MA.; specific activity $200 \mu \mathrm{Ci} / \mathrm{mmol}$ ) to a 1 liter culture of the organism in log phase growth. LTA production was then carried out as a previously described.

Animals. White New Zealand rabbits (Charles Scruggs, Shelby, NC) and Swiss-Webster and Balb/c mice (Harlan Industries, Inc., Indianapolis, IN) were used in these experiments.

Xylazine (Cutter Laboratories, Inc., Shawnee, KS; $10 \mathrm{mg} / \mathrm{kg}$ IM) and ketamine hydrochloride (Bristol Laboratories, Syracuse, $\mathrm{NY}, 50 \mathrm{mg} / \mathrm{kg} \mathrm{IM}$ ) were used for anesthesia in rabbits. Intraperitoneal pentobarbital $(0.18 \mathrm{mg} / \mathrm{g})$ was used in mice.

Excretion and toxicity of LTA were evaluated in rabbits in the following manner. Oral LTA was applied topically to the buccal mucosa of the anesthetized rabbit with a syringe in two doses of 
$0.5 \mathrm{ml} 30 \mathrm{~min}$ apart. The buccal mucosa was traumatized, where indicated, with a firm toothbrush until focal small bleeding points were observed. Urine and feces were collected in a metabolic tray where both were slightly mixed. Intravenous LTA was given by injection over a 1 -min period in the lateral ear vein.

Intratracheal injections were made under surgically sterile conditions. The anterior neck of anesthetized weanling $1.0 \mathrm{~kg}$ rabbits was shaved and prepared with $10 \%$ povidine-iodine and $70 \%$ alcohol. The skin was opened and the trachea exposed with sharp and blunt dissection.

Injection of a $0.5 \mathrm{ml}$ volume was accomplished with a needle and syringe. Needle placement was established by aspiration of air before injection. The animal was then held upright for $2 \mathrm{~min}$ to permit penetration of fluid into the lungs. The skin wound was closed with silk sutures and covered with collodion. Rabbits were sacrificed 8 days later with a lethal dose of intraperitoneal pentobarbital.

In the larger $2.0 \mathrm{~kg}$ rabbits, a tracheostomy was performed, an endotracheal tube inserted, and the animal maintained on $40 \%$ humidified oxygen. The femoral artery was catheterized, infused with heparinized saline $(1 \mathrm{U} / \mathrm{ml})$ and used for arterial blood gas samples. Serial blood gas measurements were obtained on heparinized samples obtained every $30 \mathrm{~min}$ for $4 \mathrm{~h}$. Tests were performed on the Model 213 Blood Gas Analyzer (Instrument Laboratories, Lexington, MA). Anesthesia was maintained with repeated IM injections of ketamine. Lipoteichoic acid or PBS $(0.5 \mathrm{ml})$ was instilled directly into the trachea by means of a plastic catheter inserted into the endotracheal tube. Each animal in this group served as its own control.

In mice, LTA or PBS in a $30 \mu 1$ volume was dripped rapidly on the nose of the anesthetized animal with a micropipette until it was all inhaled.

Histology. Tissues were fixed in $10 \%$ formalin and stained with hematoxylin and eosin. Sections were read blindly by two pathologists at the Medical College of Georgia.

Samples for scintillation spectrometry. Blood samples were drawn in heparinized tubes and centrifuged at $200 \times g$ for $5 \mathrm{~min}$. The plasma was removed and the $\mathrm{r}-\mathrm{RBC}$ lysed with distilled water $(0.5 \mathrm{ml}$ cells to $2.5 \mathrm{ml}$ water $)$, centrifuged at $200 \times g$ for 5 min and the supernatant retained. The cell membrane button was extracted twice with glacial acetic acid $(1 \mathrm{ml} / 0.5 \mathrm{ml}$ original volume of $r-\mathrm{RBC})$. All of the supernatants and extracts were pooled and 3 drops of $15 \%$ ascorbic acid and $10 \mathrm{ml}$ scintillation fluid (Scinti-Verse, Fisher Scientific Company, Fairlawn, NJ) added to each vial.

Urine, feces, and tissue. Samples were processed by adding 1 $\mathrm{ml}$ of NCS tissue solubilizer (Amersham Corporation, Arlington Heights, IL) to $0.5 \mathrm{ml}$ of urine and $200 \mathrm{mg}$ (wet weight) of minced tissue or feces and heated overnight in a $65^{\circ} \mathrm{C}$ water bath. The sample was cooled and $600 \mu \mathrm{l}$ of $30 \% \mathrm{H}_{2} \mathrm{O}_{2}$ was added to decolorize. The sample was heated for $4 \mathrm{~h}$ at $65^{\circ} \mathrm{C}$ to remove $\mathrm{H}_{2} \mathrm{O}_{2}$ and after cooling, $10 \mathrm{ml}$ of scintillation fluid was added.

Scintillation counting. Final reaction mixtures from urine, feces, or tissue samples were all treated with 3 drops each of $15 \%$ ascorbic acid and glacial acetic acid and $10 \mathrm{ml}$ of scintillation fluid. All were dark adapted for $24 \mathrm{~h}$ at $4^{\circ} \mathrm{C}$ and then counted for $10 \mathrm{~min} /$ vial. Tests were performed on three aliquots of each sample. The background control vial contained $600 \mu \mathrm{l} 30 \%$ $\mathrm{H}_{2} \mathrm{O}_{2}, 3$ drops of glacial acetic and $15 \%$ ascorbic acids, $0.5 \mathrm{ml}$ NCS, and $10 \mathrm{ml}$ scintillation fluid and was run in parallel with all test vials. Counting was performed on a Beckman LS-250 Scintillation Spectrometer (23).

Controls. Blood and urine from experimental rabbits, prior to LTA administration, and tissue and feces from normal rabbits served as controls. Samples from control animals were prepared in the same manner and were counted in parallel with those from LTA-treated animals.

Serum complement. Serum was tested for $\mathrm{C} 3$ concentration by a rate nephelometric method (24) in the immunopathology laboratory at Eugene Talmadge Memorial Hospital using anti- rabbit C3 (Cooper Biomedical Inc., Malvern, PA). The serum C3 concentration in three control and three experimental weanling rabbits was repeatedly measured during a 19 day period following an oral dose of LTA $(0.1,0.25,0.75 \mathrm{mg} / \mathrm{kg})$.

Platelet aggregation. Blood was drawn in $3.2 \%$ sodium citrate (1:9 volume/volume) and tested for collagen and adenosine diphosphate-induced platelet aggregation by a standard nephelometric method (25). Platelet aggregation was measured in three adult rabbits at $24 \mathrm{~h}$ after an IV dose of $\left[{ }^{3} \mathrm{H}\right] \mathrm{LTA}(0.1,0.25$, or $0.75 \mathrm{mg} / \mathrm{kg}$ doses). Six weanling $1.0 \mathrm{~kg}$ animals were also tested $24 \mathrm{~h}$ after oral LTA administration $(1.0,2.5$, and $5.0 \mathrm{mg} / \mathrm{kg}$ doses).

Autoradiography. Autoradiography of tissues was performed by a standard histologic technique (26).

Hemagglutination inhibition assay for LTA in urine. In the hemagglutination inhibition procedure, $0.5 \mathrm{ml}$ of rabbit urine and $0.5 \mathrm{ml}$ of anti-LTA antibody were incubated for $30 \mathrm{~min}$ in a $37^{\circ} \mathrm{C}$ water bath. The sample was then centrifuged at $200 \times g$ for $5 \mathrm{~min}$ and the supernatant removed for testing. LTA, that may have been present in the urine or serum, binds to the antibody. The antibody titer to LTA coated r-RBC is substantially reduced as a result.

LTA-coated $\mathrm{r}-\mathrm{RBC}$ were prepared by collecting fresh rabbit blood in an equal part of Alsever's solution, removing the r-RBC after centrifugation $(200 \times g$ for $5 \mathrm{~min})$ and washing three times with PBS. Packed r-RBC $(0.1 \mathrm{ml})$ and LTA $(1 \mathrm{mg}$ in $5 \mathrm{ml}$ of PBS) were incubated for $30 \mathrm{~min}$ at $37^{\circ} \mathrm{C}$. The $\mathrm{r}-\mathrm{RBC}$ were centrifuged, washed twice with PBS, and resuspended to a total volume of $5 \mathrm{ml}$.

Serial dilutions of anti-LTA serum and urine antibody mixtures were made in V-bottom microtiter plates. Then $0.25 \mathrm{ml}$ of $2 \%$ LTA-coated $\mathrm{r}-\mathrm{RBC}$ was added and the plates gently agitated to mix uniformly. The covered plates were allowed to stand at room temperature for $2 \mathrm{~h}$ before they were read. Agglutination of $\mathrm{r}-\mathrm{RBC}$ indicates free antibody and the absence of LTA. Absence of hemagglutination indicates the presence of LTA in the urine or serum sample. A r-RBC control (LTA coated r-RBC and PBS) and serum control (normal rabbit serum and LTA coated r-RBC) were run with each test.

\section{RESULTS}

Intravenous $\beta$ HJLTA. Five adult rabbits received an IV injection of $10 \mathrm{mg}\left[{ }^{3} \mathrm{H}\right] \mathrm{LTA}$ (sp. act. $7.7 \times 10^{-3} \mathrm{mCi} / \mathrm{mg}$ ). Tritium was not detected in samples of whole blood obtained $5 \mathrm{~min}$ to $120 \mathrm{~h}$ after an IV dose in a $2.5-\mathrm{kg}$ animal. Urine and fecal excretion of $\left[{ }^{3} \mathrm{H}\right]$ peaked at $24 \mathrm{~h}$ and decreased over 5 days (Fig. 1). Examination of tissue concentrations of $\left[{ }^{3} \mathrm{H}\right]$ by scintillation spectrometry $24 \mathrm{~h}$ after an IV dose in a $1.1 \mathrm{~kg}$ rabbit showed the greatest concentrations in colon, bone, stomach, and skin (Table

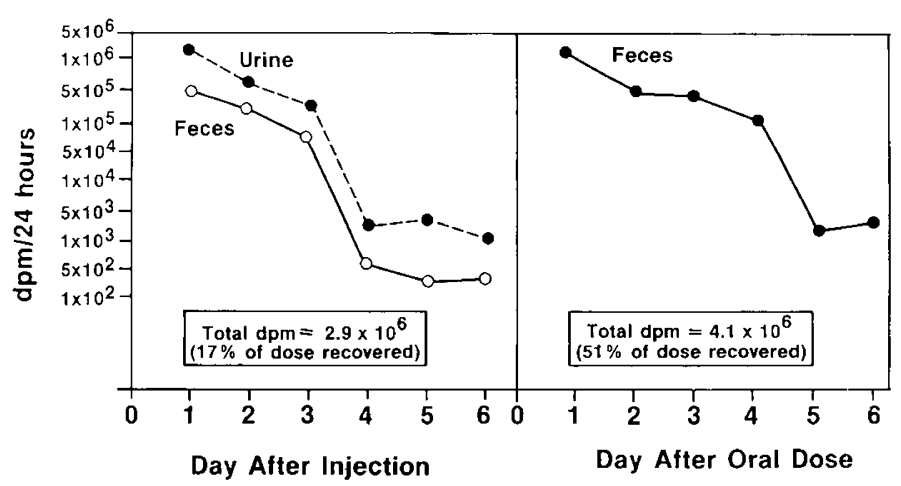

Fig. 1. Urine and fecal excretion of $\left[{ }^{3} \mathrm{H}\right] \mathrm{LTA}$. Fecal excretion after oral LTA represents a total of fecal and urine counts since the two specimens mixed during collection. The oral $\left[{ }^{3} \mathrm{H}\right] \mathrm{LTA}$ dose was $5 \mathrm{mg}$ and the IV dose $10 \mathrm{mg}$ (sp. act. $7.7 \times 10^{-3} \mathrm{mCi} / \mathrm{mg}$ ). 
1). Approximately $74 \%$ of the administered dose was recovered in the tissues and urine at $24 \mathrm{~h}$ postinjection. Excretion was primarily renal since a large amount of $\left[{ }^{3} \mathrm{H}\right]$ activity was present in bladder urine obtained by needle aspirate at autopsy (urine and fecal samples were cross-contaminated due to the method of collection). Quenching of specimens was minimal in all experiments.

Collagen (and ADP) induced platelet aggregation, measured at $6 \mathrm{~h}$ after IV injection, was increased after each LTA dose tested compared to controls. This effect increased slightly with larger doses.

LTA in urine. Results of the hemagglutination inhibition assay to demonstrate LTA in urine are given in Table 2. These data indicate that LTA was present in the urine of animals that received IV LTA.

Orally administered $\left.{ }^{\beta} H\right] L T A$. Urine and fecal excretion of $\left[{ }^{3} \mathrm{H}\right]$ was maximal at $24 \mathrm{~h}$, declined over 4 days and accounted for $51 \%$ of the $5 \mathrm{mg}\left(3.8 \times 10^{-3} \mathrm{mCi}\right)$ dose recovered in an adult animal (Fig. 1). Examination of tissue concentrations at 3 and 7 days after $5 \mathrm{mg}$ oral doses in two $2.5 \mathrm{~kg}$ animals revealed only background counts in colon, small bowel, skin, liver, kidney, spleen, and skeletal muscle. No $\left[{ }^{3} \mathrm{H}\right]$ activity was present in bladder urine obtained at autopsy at 3 days.

Tissue distribution, platelet aggregation, and $\mathrm{C} 3$ serum complement were then determined after $\left[{ }^{3} \mathrm{H}\right]$ LTA was topically applied to the normal and mechanically traumatized buccal mucosa of 30 weanling $1-\mathrm{kg}$ rabbits (15 animals/group). In each group of 15 animals, five each received $1.0,2.5$, or $5.0 \mathrm{mg}$ doses. All animals were sacrificed 3 days later. No $\left[{ }^{3} \mathrm{H}\right]$ activity was present in any of the seven tissues tested (colon, small bowel, skin, liver, kidney, spleen, and skeletal muscle). Platelet aggregation was unchanged in six animals (one animal tested/dose in each group)

Table 1. Distribution of $\left[{ }^{3} \mathrm{H}\right] 24 \mathrm{~h}$ after injection with IV $\left.{ }^{3} \mathrm{H}\right]$ LTA (10 mg; sp. act. $\left.1.7 \times 10^{6} \mathrm{dpm} / \mathrm{mg}\right)$ in a $1.1-\mathrm{kg}$ rabbit

\begin{tabular}{lll}
\hline \multicolumn{1}{c}{ Tissue } & $\mathrm{dpm} / \mathrm{g}\left(\times 10^{3}\right)$ & \multicolumn{1}{c}{$\mathrm{dpm} /$ organ } \\
\hline Colon & 68.0 & $4.1 \times 10^{3}$ \\
Bone & 29.9 & $3.3 \times 10^{6 *}$ \\
Stomach & 15.3 & $3.5 \times 10^{5}$ \\
Skin & 13.3 & $1.2 \times 10^{6 *}$ \\
Skeletal muscle & 9.7 & $1.6 \times 10^{6 *}$ \\
Spleen & 9.3 & $3.7 \times 10^{5}$ \\
Brain & 9.0 & $7.5 \times 10^{5}$ \\
Lung & 8.1 & $1.2 \times 10^{5}$ \\
Tongue & 6.4 & $2.3 \times 10^{4}$ \\
Kidney & 6.1 & $1.0 \times 10^{5}$ \\
Liver & 5.5 & $3.6 \times 10^{5}$ \\
Small bowel & 4.9 & $1.8 \times 10^{5}$ \\
Heart & 2.7 & $3.2 \times 10^{5}$ \\
Urine & $8.0($ per ml $)$ & $1.2 \times 10^{6}(150 \mathrm{ml} / 24 \mathrm{~h})$ \\
\hline
\end{tabular}

* Percent of body weight estimated: bone $=10 \%$; skin $=8 \%$; skeletal muscle $=15 \%$. Total dpm recovered $=1.2 \times 10^{7}$ (approximately $74 \%$ ). before and after LTA. Serum complement C3 did not change significantly over 19 days of observation (Table 3). No $\left[{ }^{3} \mathrm{H}\right]$ activity was present in bladder urine obtained from 17 animals at autopsy.

The buccal mucosa was histologically normal in all 30 treated weanling animals 3 days after oral LTA doses. An autoradiograph of the buccal mucosa at $24 \mathrm{~h}$ after $\left[{ }^{3} \mathrm{H}\right] \mathrm{LTA}$ administration revealed localization only on the mucosal epithelial surface without evidence of penetration in normal or traumatized animals (Fig. 2).

Examination of the kidneys at autopsy 3 days after two $\left[{ }^{3} \mathrm{H}\right]$ LTA oral doses revealed microscopic evidence of nephrocalcinosis in 17 of $30(57 \%)$ animals. It occurred in five of eight $(63 \%)$ male and 12 of $22(55 \%)$ female animals. None of nine salinetreated weanling rabbits obtained from a second supplier had nephrocalcinosis.

In order to confirm the previous finds regarding nephrocalcinosis, 30 weanling, female rabbits were obtained from a third supplier. Two groups of 15 animals received either oral or intravenous treatment. Five animals/group received PBS, five received $0.5 \mathrm{mg}$, and five received $1.0 \mathrm{mg}$ of LTA as previously described for each route of administration. Animals were sacrificed 7 days later. Results revealed microscopic nephrocalcinosis (usually one or two lesions $<1 \mathrm{~mm}$ in size) in six of $10(60 \%)$ PBS controls (three each/group). In LTA-treated animals, three of $20(15 \%)$ had nephrocalcinosis (one at each oral dose and one at the $0.5 \mathrm{mg}$ IV dose).

Pulmonary aspiration of LTA. Since experiments in the recent literature $(20)$ have shown pulmonary toxicity with aspiration of LTA from GBS, the aspiration experiments were repeated. Thirty anesthetized Swiss-Webster mice were treated with PBS and 30 with LTA $(30 \mu \mathrm{l}$ volume containing 1 or $2 \mathrm{mg} \mathrm{LTA} / \mathrm{ml} ; 15$ animals/group). All PBS- and LTA-treated mice become tachypneic immediately following aspiration (within $5 \mathrm{~min}$ ). Two of $30(7 \%)$ control and one of $30(3 \%)$ LTA-treated mice $(2 \mathrm{mg}$ dose) died within $5 \frac{1}{2} \mathrm{~h}$. All other animals recovered from the tachypnea $2-3 \mathrm{~h}$ after treatment. They remained normal over 1 wk of observation.

The experiment was repeated 7 days later using the surviving mice but reversing the experimental groups. All animals again became tachypneic within $5 \mathrm{~min}$. Two of $29(7 \%)$ control and one of 28 (3\%) LTA-treated animals died after treatment. Remaining animals all recovered uneventfully.

Histologic examination of the lungs at autopsy revealed mild to moderate focal edema, congestion, and hemorrhage in animals from the initial experiment. Lungs of animals dying in the second experiment revealed areas of mild focal, interstitial pneumonia, and congestion (no bacteria noted with MacCallum's stain), most likely due to aspiration 1 wk previously.

The experiment was also repeated in $20 \mathrm{Balb} / \mathrm{c}$ mice $(10$ controls and 10 LTA treated with $30 \mu \mathrm{l}$ of a solution containing $2 \mathrm{mg} \mathrm{LTA} / \mathrm{ml}$ ). All became tachypneic immediately but none died during 1 wk of observation.

This technique was not useful for evaluating toxicity since

Table 2. Hemagglutination inhibition test for LTA in urine

\begin{tabular}{lcc}
\hline \multicolumn{1}{c}{ Incubation mixture } & $\begin{array}{c}\text { Hemagglutination } \\
\text { titer }\end{array}$ & Significance \\
\hline LTA coated r-RBC and anti-LTA serum & $1: 512$ & Positive test control \\
Normal rabbit urine and anti-LTA serum; then LTA-coated r-RBC & $1: 512$ & Negative urine control \\
$\begin{array}{l}\text { Urine from rabbit given IV LTA (72 h after dose; add anti-LTA serum; } \\
\text { then LTA-coated r-RBC }\end{array}$ & None & LTA present in urine \\
$\begin{array}{l}\text { Normal rabbit serum and LTA-coated r-RBC } \\
\text { LTA-coated r-RBC and PBS }\end{array}$ & None & Negative serum control \\
\end{tabular}


Table 3. Relative serum concentrations of $C 3$ complement before and after oral LTA in weanling rabbits

\begin{tabular}{|c|c|c|}
\hline & & $\mathrm{C} 3^{*}$ \\
\hline \multirow[t]{6}{*}{ Rabbit $1(0.1 \mathrm{mg} / \mathrm{kg})$} & Before dose & 4.5 \\
\hline & After dose & \\
\hline & $1.5 \mathrm{~h}$ & $\begin{array}{l}4.9 \\
4.0\end{array}$ \\
\hline & $\begin{aligned} 0 \mathrm{n} \\
24 \mathrm{~h}\end{aligned}$ & 4.5 \\
\hline & 12 days & 5.4 \\
\hline & 19 days & 4.8 \\
\hline \multirow[t]{7}{*}{ Rabbit $2(0.25 \mathrm{mg} / \mathrm{kg})$} & Before dose & 7.2 \\
\hline & After dose & \\
\hline & $1.5 \mathrm{~h}$ & 4.9 \\
\hline & $6 \mathrm{~h}$ & 7.4 \\
\hline & $24 \mathrm{~h}$ & 10.8 \\
\hline & 12 days & 3.7 \\
\hline & 19 days & 6.0 \\
\hline \multirow[t]{7}{*}{ Rabbit $3(0.75 \mathrm{mg} / \mathrm{kg})$} & Before dose & 2.4 \\
\hline & After Dose & \\
\hline & $1.5 \mathrm{~h}$ & 4.4 \\
\hline & $6 \mathrm{~h}$ & 2.2 \\
\hline & $24 \mathrm{~h}$ & 9.8 \\
\hline & 12 days & 6.8 \\
\hline & 19 days & 3.7 \\
\hline
\end{tabular}

$\begin{array}{ccc}\text { Controls } & & \\ 4 & 5.2 & \text { Mean of 6 rabbits (including baseline } \\ 5 & 4.0 & \text { values in LTA-treated animals) }= \\ 6 & 6.7 & 5.0 \pm 1.4 \text { (SD) }\end{array}$

* Numbers represent nephelometric readings in $\mathrm{mV}$. Each value represents the mean of two determinations. Serum samples were diluted $1: 10$ before testing. A higher voltage reading is associated with a higher C3 concentration.

tachypnea or death due to aspiration were noted in both control and treated animals. In order to avoid this difficulty, intratracheal injections were performed in 10 weanling rabbits. Each rabbit received $0.5 \mathrm{ml}$ of LTA $(2 \mathrm{mg} / \mathrm{kg}$ ) or sterile PBS (five animals/ group).

One LTA-treated animal died 7 days after treatment but no respiratory distress was noted anytime prior to death. None of the other animals developed respiratory distress. At autopsy, tracheal congestion and focal bronchial hemorrhage was seen in control and LTA-treated animals. Interstitial pneumonia (nonbacterial by MacCallum's stain) was present in two of five LTAtreated and four of five control animals.

Since control and treated animals developed pulmonary hemorrhage and pneumonia related to the surgical procedure and aspiration, the instillation was repeated through a plastic catheter during endotracheal intubation in two $2.0-\mathrm{kg}$ rabbits. One animal received $0.5 \mathrm{mg} / \mathrm{kg}$ and the other $2.5 \mathrm{mg} / \mathrm{kg}$ of LTA.

Serial arterial blood gas measurements (Fig. 3) did not change significantly during $4 \mathrm{~h}$ of observation. Tachypnea was not observed in either animal.

\section{DISCUSSION}

This study demonstrated that LTA from GBS is not toxic to rabbits when administered by the oral or intratracheal route. When administered orally, no systemic absorption occurred. Intravenous administration resulted in increased platelet aggregation without observable toxicity to the animal. Topical mucosal or oral administration of LTA from GBS should be safe in human subjects since it is neither absorbed nor toxic.

IV LTA was rapidly concentrated in tissue; none could be detected in blood within 5 min after injection. Most of the dose was concentrated in the gastrointestinal tract, bone, and skin. Reasons for the specific tissue affinities are not known, although the gastrointestinal tract is frequently colonized with GBS in $\operatorname{man}(27)$.

LTA was excreted in urine after intravenous and in feces after oral administration over 4 to 5 days. The small molecular weight of LTA from GBS 10-15,000 daltons (Mattingly S, personal communication) suggests that it would be filterable through the glomerulus and be found in urine after IV injection. Four hours after intradermal injection, LTA from group A streptococci was found in the cortical tubular regions closely associated with glomeruli, but glomeruli themselves showed little LTA deposition (17). The absence of oral absorption of LTA may be due to its rapid adherence to and slow elution from cell membranes (5, 28, 29).

Although there is no well-documented cross-reactivity, LTA from group A streptococci reportedly inhibits attachment of GBS to buccal epithelial cells in humans (30). In the hemagglutination assay in the present study, LTA from GBS reacted to group A streptococcal antibody, thus demonstrating cross-reactivity. It is therefore possible for hemagglutination to have been inhibited by LTA from group A streptococci. However, rabbits are not naturally colonized with either group A or B streptococci and urine from control animals contained no cross-reactive LTA.

There have been no previous studies of oral absorption or toxicity of lipoteichoic acids. Data obtained from studies of a related bacterial product, endotoxin revealed that it was not absorbed after topical application to normal gingival mucosa in rabbits (31). Diffuse chemical injury, but not focal mechanical trauma to the mucosa, did result in a local Schwartzman reaction after a subsequent dose of endotoxin. Tritiated endotoxin ( 86 $\mu \mathrm{g}$ ) dripped on the normal gingiva of dogs every $5 \mathrm{~min}$ for $2 \mathrm{~h}$ resulted in some of the label appearing around vessels in the gingival lamina propia after $24 \mathrm{~h}$ (32). No toxicity was described. In the present study, autoradiography of the rabbit buccal mucosa (after exposure to topical [ ${ }^{3} \mathrm{H}$ ]LTA for 30 to $60 \mathrm{~min}$ ) revealed localization restricted to the surface epithelium in animals with or without focal trauma.

Previous studies in rabbits have reported an increased rate of nephrocalcinosis after 3 wk of IV administration of LTA from group A streptococci. However, $32 \%$ of control rabbits also had nephrocalcinosis (17). Female animals were affected more often $(100 \%)$ than males $(64 \%)$. In the present study, microscopic nephrocalcinosis was noted in $57 \%$ of animals 3 days after oral LTA administration at which time no measurable systemic absorption had occurred. LTA-treated female animals also had the same incidence of nephrocalcinosis as control females (54\%) in the previous study (17). Control rabbits from a second supplier showed no evidence of nephrocalcinosis after saline injections. Repetition of the experiment using female animals from a third supplier revealed a significantly increased $\left(\chi^{2}=4.28, p=\sim 0.05\right)$ incidence of nephrocalcinosis in control animals. These data suggest that the nephrocalcinosis noted in our study was related to dietary, breeding, or other unknown factors in different lots of animals and not to LTA administration. The high frequency of naturally occurring nephrocalcinosis in rabbits is related to the alkaline $\mathrm{pH}$ of their urine (17).

Pulmonary aspiration of LTA produced no toxicity in two strains of mice. The hemorrhage and congestion, noted at autopsy, in the lungs of animals that died was due to aspiration and not LTA since control animals had the same frequency and type of findings. Another study (20) has shown that inhaled LTA from GBS causes pulmonary hemorrhage and death in small numbers of mice. Reasons for the difference in the two studies are unknown but hot hydrochloric acid extraction was not employed in LTA production in the present study but was used by Wennerstrom (personal communication). Larger volumes of LTA solution may also have entered the lung through the nasopharynx resulting in toxicity and death from aspiration alone.

Intratracheal administration of LTA rabbits provided a mech- 


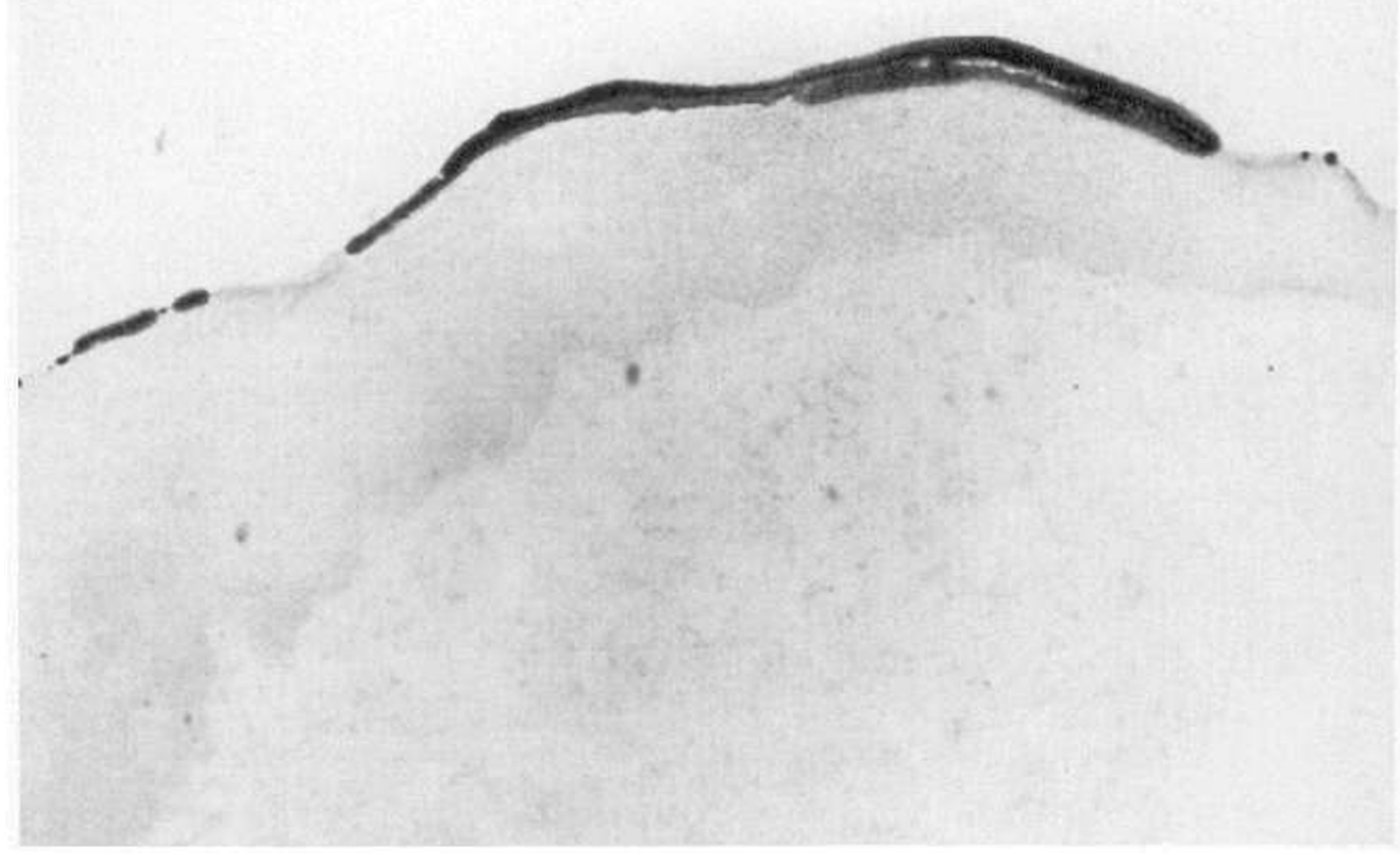

Fig. 2. Autoradiograph of normal buccal mucosa $(\times 100) 24 \mathrm{~h}$ after topical in vivo application of $\left[{ }^{3} \mathrm{H}\right] \mathrm{LTA}\left(5 \mathrm{mg} ; \mathrm{sp} . \mathrm{act} .7 .7 \times 10^{-3} \mathrm{mCi} / \mathrm{mg}\right)$.
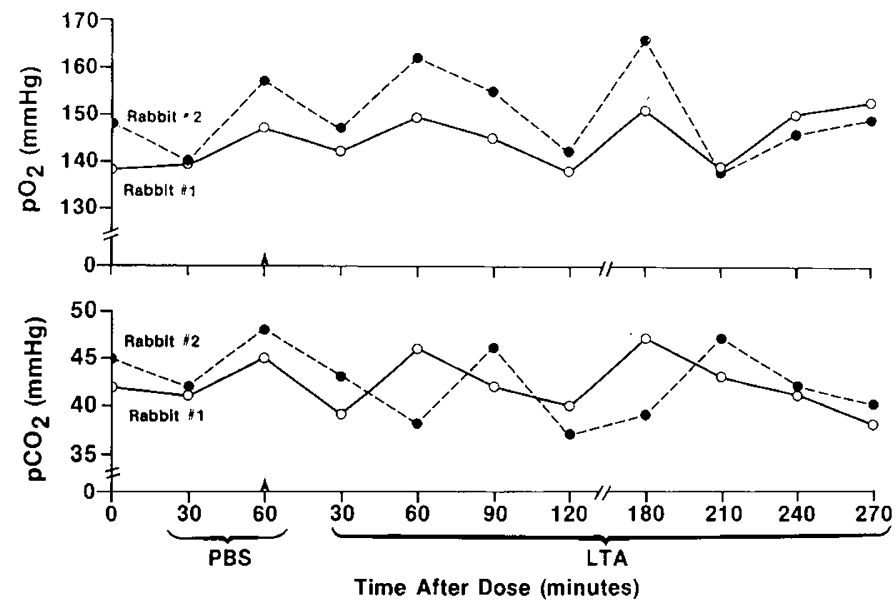

Fig. 3. Arterial oxygen $\left(\mathrm{pO}_{2}\right)$ and carbon dioxide $\left(\mathrm{pCO}_{2}\right)$ tension before and after aspiration of PBS or LTA. A $0.5-\mathrm{ml}$ volume of LTA or PBS was injected into the trachea with a syringe and polyethylene catheter through an endotracheal tube. All of the injected material remained in the lungs. Each rabbit weighed $2.0 \mathrm{~kg}$ and was maintained on an inspired oxygen concentration of $40 \%$ during the experiments. Rabbit 1 received $1 \mathrm{mg}$ and rabbit 2 received $5 \mathrm{mg}$ of LTA. Timing of the LTA injection is indicated by the arrows.

anism of delivery of the whole sample into the lungs. Although no toxicity or tachypnea was noted over 8 days, pulmonary hemorrhage, pneumonia, and congestion resulted from the surgical procedure and aspiration in control and LTA-treated rab- bits. The small size of the animals did not readily permit percutaneous intratracheal injections. Finally, however, intratracheal instillation through an endotracheal tube produced neither tachypnea nor changes in arterial blood gases. This method proved to be adequate in assessing acute pulmonary toxicity in rabbits.

In summary, LTA from GBS was neither toxic nor absorbed after oral administration and nontoxic after intratracheal instillation. In a previous study, topical oral and cutaneous application of LTA to newborn mice was nontoxic and completely prevented GBS colonization of neonates by their vaginally colonized mothers (5). Topical application of LTA to human neonates may also prevent GBS colonization after contact with maternal mucosal and skin surfaces at birth. The lack of absorption and toxicity in animal models suggest that such a study may be performed safely.

Acknowledgments. The authors are grateful to Mable Jackson for typing the manuscript, to Luann Taylor for technical assistance, and Albert Pruitt, M.D. for review of the manuscript. Wild strain type III (DS-2434-80) GBS was supplied by Richard Facklam, Ph.D. at the Centers for Disease Control in Atlanta, GA. Rabbit serum (decomplemented) containing antibody to group A streptoccoal LTA was supplied by Dr. Robert Jackson at Southern Illinois University.

\section{REFERENCES}

1. Boyer KM, Gadzala CA, Burd LI, Fisher DE, Paton JB, Gotoff SP 1983 Selective intrapartum chemoprophylaxis of neonatal group B streptococcal early-onset disease. I. Epidemiologic rationale. II. Predictive value of prenatal cultures. III. Interruption of mother-to-infant transmission. J Infect Dis 148:795-801, 802-809, 810-816

2. Editorial 1983 Interview with Carol Baker, M.D., Prevention of neonatal group B streptococcal disease. Pediatr Infect Dis 2:1-5 
3. Beachey EH 1975 Binding of group A streptococci to human oral mucosal cells by lipoteichoic acid. Trans Assoc Am Phys 88:285-292

4. Nealon TJ, Mattingly SJ 1984 Role of cellular lipoteichoic acids in mediating adherence of serotype III strains of group B streptococci to human embryonic, fetal, and adult epithelial cells. Infect Immun 43:523-530

5. Cox F 1982 Prevention of group B streptococcal colonization with topically applied lipoteichoic acid in a maternal-newborn mouse model. Pediatr Res $16: 816-819$

6. Silvestri LJ, Know KW, Wicken AJ, Hoffman EM 1979 Inhibition of complement-mediated lysis of sheep erythrocytes by cell-free preparations from Streptococcus mutans BHT. J Immunol 122:54-60

7. Beachey EH, Dale JB, Grebe S, Ahmed S, Simpson WA, Ofek I 1979 Lymphocyte binding and $\mathrm{T}$ cell mitogenic properties of group A streptococcal lipoteichoic acid. J Immunol 122:189-195

8. Miller GA, Urban J, Jackson RW 1976 Effects of a streptococcal lipoteichoic acid on host responses in mice. Infect Immun 13:1408-1417

9. Beachey EH, Chiang TM, Ofek I, Kang AH 1977 Interaction of lipoteichoic acid of group A streptococci with human platelets. Infect Immun 16:649654

10. DeVuono J, Panos C 1978 Effect of L-form Streptococcus pyogenes and of lipoteichoic acid on human cells in tissue culture. Infect Immun 22:255-265

11. Goldschmidt JC, Panos C 1984 Teichoic acids of Streptococcus agalactiae: chemistry, cytotoxicity, and effect on bacterial adherence to human cells in tissue culture. Infect Immun 43:670-677

12. Simpson WA, Dale JB, Beachey EH 1982 Cytotoxicity of the glycolipid region of streptococcal lipoteichoic acid for cultures of human heart cells. J Lab Clin Med 99:118-126

13. Hausmann E, Luderitz O, Knox K, Weinfeld N 1975 Structural requirements for bone resorption by endotoxin and lipoteichoic acid. J Dent Res 54:B94B99

14. Harrop PJ, O'Grady RL, Knox KW, Wicken AJ 1980 Stimulation of lysosomal enzyme release from macrophages by lipoteichoic acid. J Periodont Res 15:492-501

15. Fiedel BA, Jackson RW 1976 Immunogenicity of purified and carrier complexed lipoteichoic acid. Infect Immun 13:1585-1590

16. Fiedel BA, Jackson RW 1979 Nephropathy in the rabbit associated with immunization to a group A streptococcal lipoteichoic acid. Med Microbiol Immunol 167:251-260

17. Waltersdorff RL, Fiedel BA, Jackson RW 1977 Induction of nephrocalcinosis in rabbit kidneys after long-term exposure to a streptococcal teichoic acid.
Infect Immun 17:665-667

18. Miller GA, Jackson RW 1973 The effect of a Streptococcus pyogenes teichoic acid on the immune response of mice. J Immunol 110:148-156

19. Ne'eman N, Ginsburg I 1972 Red cell-sensitizing antigen of group A streptococci. II. Immunological and immunopathological properties. Isr J Med Sci $8: 1807-1816$

20. Wennerstrom DE 1983 Effect of lipoteichoic acid from group B streptococci type Ia on the lungs of mice. 83rd Annual Meeting American Society of Microbiology, Abstract B38.

21. Wennerstrom DE 1984 Group B streptococcal lipoteichoic acid enhances infection and alters pulmonary surfactant. 84th Annual Meeting American Society for Microbiology, Abstract B47.

22. Alkan ML, Beachey EH 1978 Excretion of lipoteichoic acid by group A streptococci. Influence of penicillin on excretion and loss of ability to adhere to human oral mucosal cells. J Clin Invest 61:671-677

23. Long EC 1976 Liquid scintillation counting theory and techniques. Beckman Instruments Inc, Fullerton, CA, Technical Report 915-NUC-76-7T P/N 566671

24. Sternberg JC 1977 A rate nephelometer for measuring specific proteins by immunoprecipitin reactions. Clin Chem 23:1456-1464

25. Born GWR, Cross MJ 1963 The aggregation of blood platelets. J Physiol (Lond) 168:178-195

26. Bancroft JD, Stevens A 1977 Theory and practice of histological techniques. Churchill Livingstone, London, pp 371-386

27. Anthony BF, Carter JA, Eisenstadt R, Rimer DG 1983 Isolation of group B streptococci from the proximal small intestine of adults. J Infect Dis 147:776

28. Beachey EH, Dale JB, Simpson WA, Evans JD, Knox KW, Ofek I, Wicken AJ 1979 Erythrocyte binding properties of streptococcal lipoteichoic acids. Infect Immun 23:618-625

29. Ofek I, Beachey EH, Jefferson W, Campbell GL 1975 Cell membrane-binding properties of group A streptococcal lipoteichoic acid. J Exp Med 141:9901003

30. Simpson WA, Ofek I, Sarasohn C, Morrison JC, Beachey EH 1980 Characteristics of the binding of streptococcal lipoteichoic acid to human oral epithelial cells. J Infect Dis 141:457-462

31. Rizzo AA 1968 Absorption of bacterial endotoxin into rabbit gingival pocket tissue. Periodontics 6:65-70

32. Schwartz J, Stinson FL, Parker RB 1972 The passage of tritiated bacterial endotoxin across intact gingival crevicular epithelium. J Periodontol 43:270276 